\title{
Attitudes and Behavior of Dental Students Concerning Infection Control Rules: A Study with a10-Year Interval
}

\author{
Mauro Henrique Nogueira Guimarães de ABREU ${ }^{1}$ \\ Maria Claudia LOPES-TERRA ${ }^{2}$ \\ Leila Fátima BRAZ2 \\ Alcione Lúcia RÍMULO ${ }^{3}$ \\ Saul Martins PAIVA ${ }^{4}$ \\ Isabela Almeida PORDEUS ${ }^{4}$ \\ ${ }^{1}$ Department of Community and Preventive Dentistry, Federal University of Minas Gerais, Belo Horizonte, MG, Brazil
\[ \begin{array}{r}{ }^{2} \text { Brazilian Dental Association, Belo Horizonte, MG, Brazil } \\ { }^{3} \text { University of Itaúna, Itaúna, MG, Brazil }\end{array} \]
${ }^{4}$ Department of Pediatric Dentistry and Orthodontics, Federal University of Minas Gerais, Belo Horizonte, MG, Brazil
}

The study compared the attitudes and behavior of 4th-year dental students regarding infection control rules in 1995 and 2005 . Selfadministrated questionnaires were applied to 592 students at 5 different dental schools in 1995 ( $\mathrm{n}=350)$ and in 2005 ( $\mathrm{n}=242$ ). The chi-square and Fisher's exact tests were used for statistical analysis of data. Significance level was set at $\mathrm{p}<0.05$. The response rate was $90.3 \%$ in 1995 and $81.0 \%$ in 2005 . There was no improvement in the use of rubber gloves $(\mathrm{p}=0.316)$, face masks $(\mathrm{p}=0.572)$ or gowns $(p=0.862)$ between 1995 and 2005. There was a lesser frequency of the use of protective eyewear in 2005 ( $<<0.001)$. No student used the individual protection equipment correctly. There was a decrease in the sterilization of burs in 2005 when compared to 1995 ( $\mathrm{p}<0.001)$. No student could describe the correct use of the autoclave. Disinfection and use of a dental chair barrier were done correctly by a minority of students in $1995(2.8 \%)$ and $2005(6.1 \%)(\mathrm{p}=0.069)$. Most students correctly discarded perforating/cutting instruments in both years $(\mathrm{p}=0.749)$. The attitudes and behavior of dental students concerning infection control are worrisome. There was no improvement and, for some parameters, there was a worsening in the procedures over the time period evaluated.

Key Words: infection control, dental students, dental school.

\section{INTRODUCTION}

The oral cavity is a fertile environment for the transmission, inoculation and growth of various infectious agents. There are microorganisms in an individual that may not cause any harm to the particular host, but can be detrimental to others. Blood and saliva are the ideal means for transmitting such agents (1).

Despite the considerable emphasis that has been placed on standardized infection control procedures, it appears that few dentists have adhered to these procedures in their clinical practice (1-8). Even in dental schools, future dentists have not properly adhered to these procedures (9-15). Studies have demonstrated that knowledge on infection control is higher than that employed in dental practice $(2,9,10)$.

Dental education can play an important role in the training of dentists, helping them to adopt adequate attitudes related to infection control. There are few longitudinal studies on infection control involving dental students (16). The aim of the present study was to compare the attitudes and behavior with regard to infection control rules among 4th-year students in 1995 and 2005 at 5 dental schools in the state of Minas Gerais, Brazil. The null hypotheses was that there are no differences in the attitudes and behavior with regard to infection 
control rules between the 4th-year students evaluated in 1995 and in 2005.

\section{MATERIAL AND METHODS}

The sample was composed by 592 4th year students attending 3 public and 2 private dental schools in the state of Minas Gerais, Brazil in 1995 and in 2005. The dean of each dental school was personally contacted by the researchers, who informed the study purposes and the methodology to be employed.

A self-administrated questionnaire consisting of 13 close-ended items was used for data collection. All participants were given information on the survey distribution as well as the number and type of questions, topics covered and the assurance that the anonymity would be maintained. Although the questionnaire employed was not formally validated, a pilot study was previously carried out to test students' understanding of the instrument addressing attitudes and behavior regarding cross-infection control. Ten students (not included in the main study) at one dental school took part in this pilot phase. Their comments were helpful for improving the questionnaire. The study was approved by Research Ethics Committee of the State University of Montes Claros, Brazil. All participants signed informed consent forms and the questionnaires were personally handed out to each student.

The questionnaires addressed the following topics: hand drying with paper towel; surface disinfection with chemical substance and protection with impermeable material; bur sterilization; dental impression disinfection; discarding perforating/cutting material in rigid covered recipient; autoclave use; correct autoclave use; perception of Hepatitis B immunization; submission to seroconversion test; use of rubber gloves, protective eyewear, face masks and gowns. The same methodology was employed in both 1995 and 2005. The evaluation parameters of proper infection control standards were based on recommendations from the US Centers of Disease Control (CDC) and the Brazilian Ministry of Health $(1,16)$.

The answers were recorded and processed using the Statistic Package for Social Sciences (SPSS for Windows version 11.0; SPSS Inc., Chicago, IL, USA). The chi-square and Fisher's exact tests were employed when indicated in the statistical analyses to compare differences in the proportion of attitudes and behavior among dental students in 1995 and in 2005. Statistical significance was set at $\mathrm{p}<0.05$.

\section{RESULTS}

Three hundred and sixteen people took part in the study in 1995 and 196 took part in 2005. The response rate was $90.3 \%$ in 1995 and $81.0 \%$ and 2005 . The students treated an mean of $2.5 \pm 1.4$ patients daily in 1995 and $2.3 \pm 0.9$ in 2005 .

Concerning hand care after washing, there was an increase in the proportion of students that used paper towels $(p=0.006)$. The proportion of students who reported disinfection followed by surface protection with an impermeable material on the dental chair was low in both years. There was a decrease in the sterilization of burs in 2005 when compared to 1995 ( $p<0.001)$. Most students did not disinfect dental impressions in either year $(p=0.517)$. Nearly all the students discarded perforating/cutting material in adequate recipients in both years $(\mathrm{p}=0.749)$ (Table 1$)$.

In 1995, most students used an autoclave to sterilize instruments $(83.8 \%)$ and this percentage increased in $2005(95.9 \%)(p<0.001)$. However, no student could describe the correct pressure, temperature and sterilization time in either 1995 or 2005 . There was an increase in the proportion of students who failed to answer this question $(\mathrm{p}<0.001)$ (Table 1).

Most students reported being vaccinated for Hepatitis $\mathrm{B}(95.6 \%$ in 1995 and $95.4 \%$ in 2005) $(\mathrm{p}=0.278)$. However, a minority of the students reported having taken the seroconversion test (13.9\% in 1995 and $14.8 \%$ in 2005) $(\mathrm{p}=0.294)$ (Table 1).

The great majority of the students wore rubber gloves (98.1\%), face masks (97.2\%), gowns (97.2\%) and protective eyewear $(66.1 \%)$ during all procedures and with all patients in 1995. Ten years later, percentages regarding individual protection equipment (IPE) were $98.0 \%$ for rubber gloves, $55.1 \%$ for protective eyewear, $95.9 \%$ for face masks and $97.4 \%$ for gowns. The only statistically significant difference was the reduction in the proportion of students who wore protective eyewear correctly $(p<0.001)$ (Table 2$)$. When the use of complete IPE was analyzed together, no student reported using all items at the same time.

\section{DISCUSSION}

The results of the present study reveal student 
Table 1. Distribution of dental students' attitudes and behavior concerning infection control rules, MG, Brazil (1995 and 2005$).$

\begin{tabular}{|c|c|c|c|c|c|}
\hline Attitudes and behavior & Year & Yes $(\%)$ & No $(\%)$ & NI (\%) & $\mathrm{p}$ value \\
\hline \multirow{2}{*}{ Hand drying with paper towel } & 1995 & $269(85.1)$ & $34(10.8)$ & $13(4.1)$ & \multirow{2}{*}{$0.006^{*}$} \\
\hline & 2005 & $185(94.4)$ & $8(4.1)$ & $3(1.5)$ & \\
\hline \multirow{2}{*}{$\begin{array}{l}\text { Surface disinfection with chemical substance } \\
\text { and protection with impermeable material }\end{array}$} & 1995 & $9(2.8)$ & $307(97.2)$ & $0(0.0)$ & \multirow{2}{*}{$0.069^{*}$} \\
\hline & 2005 & $12(6.1)$ & $184(93.9)$ & $0(0.0)$ & \\
\hline \multirow{2}{*}{ Bur sterilization } & 1995 & $201(63.6)$ & $103(32.6)$ & $12(3.8)$ & \multirow{2}{*}{$<0.001 * *$} \\
\hline & 2005 & $81(41.3)$ & $114(58.2)$ & $1(0.5)$ & \\
\hline \multirow{2}{*}{ Dental impression disinfection } & 1995 & $106(33.5)$ & $205(64.9)$ & $5(1.6)$ & \multirow{2}{*}{$0.517 * *$} \\
\hline & 2005 & $57(29.1)$ & $137(69.9)$ & $2(1.0)$ & \\
\hline \multirow{2}{*}{$\begin{array}{l}\text { Perforate-cutting material discard in covered } \\
\text { rigid recipient }\end{array}$} & 1995 & $303(95.9)$ & $11(3.5)$ & $2(0.6)$ & \multirow{2}{*}{$0.749 * *$} \\
\hline & 2005 & $191(97.5)$ & $4(2.0)$ & $1(0.5)$ & \\
\hline \multirow{2}{*}{ Autoclave use } & 1995 & $265(83.8)$ & $41(13.0)$ & $10(3.2)$ & \multirow{2}{*}{$<0.001^{*}$} \\
\hline & 2005 & $188(95.9)$ & $2(1.0)$ & $6(3.1)$ & \\
\hline \multirow[b]{2}{*}{ Correct autoclave use } & 1995 & $0(0.0)$ & $43(13.6)$ & $273(86.4)$ & \multirow{2}{*}{$<0.001^{*}$} \\
\hline & 2005 & $0(0.0)$ & $1(0.5)$ & $195(99.5)$ & \\
\hline \multirow{2}{*}{ Hepatitis B vaccination } & 1995 & $302(95.6)$ & $8(2.5)$ & $6(1.9)$ & \multirow{2}{*}{$0.278^{* *}$} \\
\hline & 2005 & $187(95.4)$ & $8(4.1)$ & $1(0.5)$ & \\
\hline \multirow[b]{2}{*}{ Seroconversion testing } & 1995 & $44(13.9)$ & $219(69.3)$ & $53(16.8)$ & \multirow{2}{*}{$0.294^{*}$} \\
\hline & 2005 & $29(14.8)$ & $124(62.3)$ & 43 (21.9) & \\
\hline
\end{tabular}

NI - No information; *Chi-square test; **Fisher's exact test.

Table 2. Distribution of dental students' attitudes and knowledge of use of individual protective equipment (IPE), MG, Brazil (1995 and 2005).

\begin{tabular}{|c|c|c|c|c|c|c|}
\hline IPE & Year & $\mathrm{A}(\%)$ & B $(\%)$ & $\mathrm{C}(\%)$ & $\mathrm{D}(\%)$ & $\mathrm{p}$ value \\
\hline \multirow{2}{*}{ Rubber gloves } & 1995 & $312(98.8)$ & $2(0.6)$ & $2(0.6)$ & $0(0.0)$ & \multirow{2}{*}{$0.316^{* *}$} \\
\hline & 2005 & $192(98.0)$ & $3(1.5)$ & $0(0.0)$ & $1(0.5)$ & \\
\hline \multirow{2}{*}{ Protective glasses } & 1995 & $207(65.5)$ & $95(30.1)$ & $3(0.9)$ & $11(3.5)$ & \multirow{2}{*}{$<0.001 *$} \\
\hline & 2005 & $108(55.1)$ & $59(30.1)$ & $3(1.5)$ & $26(13.3)$ & \\
\hline \multirow{2}{*}{ Face masks } & 1995 & 307 (97.2) & $8(2.5)$ & $1(0.3)$ & $0(0.0)$ & \multirow{2}{*}{$0.572 * *$} \\
\hline & 2005 & $188(95.9)$ & $8(4.1)$ & $0(0.0)$ & $0(0.0)$ & \\
\hline \multirow{2}{*}{ Gowns } & 1995 & $309(97.8)$ & $4(1.3)$ & $2(0.6)$ & $1(0.3)$ & \multirow{2}{*}{$0.862 * *$} \\
\hline & 2005 & $191(97.5)$ & $4(2.0)$ & $1(0.5)$ & $0(0.0)$ & \\
\hline
\end{tabular}

$\mathrm{A}=$ use in all patients and all procedures; $\mathrm{B}=$ use in all patients but some procedures; $\mathrm{C}=$ use in all procedures, but in some patients; $\mathrm{D}=$ use in some procedures and in some patients; *Chi-square test; **Fisher's exact test. 
behavior regarding infection control at 5 dental schools in the state of Minas Gerais, Brazil. This is a study with internal validity, which means these data cannot be extrapolated to the entire country and/or other countries. However, there has been sparse literature on the longitudinal evaluation of infection control procedures among dental students. The decision evaluating 4th-year dental students was due to the fact that these students are in the last year of the undergraduate program and should therefore have a more complete theoretical and practical background regarding infection control in order to become dentists. Furthermore, assessments at this phase may be indicative of the capacity of dental courses in incorporating adequate behavior regarding infection control among future dentists.

The data are worrisome, as only 2 of the 13 parameters evaluated improved in the 10 -year interval: the use of paper towels and the autoclave. As these items are provided by the dental schools, it may be suggested that access to these 2 resources in dental clinics also improved. Correct hand drying techniques and the use of safer sterilization equipment were likely more frequently available in 2005 than in 1995 . However, some students still reported not drying their hands with a paper towel, which goes against the recommendations $(1,16)$. A greater use of an autoclave was observed in the USA back in 1987 when compared to 1982 (17).

Along with the improvement in the abovementioned topics, most of the dental students surveyed discarded perforating/cutting material in rigid covered recipients, in compliance with the recommendations of the Brazilian Ministry of Health (6). It therefore seems that this practice is not a problem in the training of future dentists. Despite this positive point, there were many worrisome results, as the proportion of students who failed to adopt the proper attitudes remained the same over time and, in some cases, this proportion actually increased. Regarding the parameters that did not achieve different results $(\mathrm{p}>0.05)$, surface disinfection and protection with impermeable material on dental chairs should be emphasized. A minority of the students reported adopting the correct cleaning procedure in both years. The recommendations determine that all surfaces that may become contaminated and those of difficult decontamination should be covered. Covers must be fabricated in impermeable material and discarded after patient care $(1,16)$.

Disinfection of dental impressions was not per- formed by approximately 7 out of 10 students in both years, which confirms findings in the USA (17). After dental impression procedures and before sending the impressions to the laboratory or for plastering, the models must be decontaminated in order to remove saliva, blood and other debris. Disinfecting substances must then be used. Previous washing and decontamination avoid sending contaminated material to the prosthesis laboratory $(1,16)$.

The correct use of IPE was not carried out by any of the students in either year. This is very worrisome, considering the importance of IPE for infection control in dental practice. It also suggests that the accumulated scientific knowledge regarding infection control has not changed the attitudes of future dentists in a 10-year interval. However, Souza et al. (12) found a greater frequency of compliance with the use of IPE than that described in the present study. The proportion of students who wore rubber gloves, face masks and gowns correctly was maintained $(\mathrm{p}>0.05)$, whereas there was a decrease in the proportion of who wore protective eyewear $(p<0.05)$, despite the recommendations of the literature $(1,16)$. A recent study revealed that the incomplete use of IPE by dental students at the Federal University of Minas Gerais was independently associated with exposure to blood (18).

It is recommended that both students and professors be vaccinated in order to reduce the risk of infection. By doing so, they protect not only healthcare professionals, but also patients and relatives $(1,16)$. Most students were vaccinated against hepatitis B in 1995 and 2005. In a study carried out in Rio de Janeiro (Brazil), the proportion of vaccinated students was similar to that found in the present study (12). However, most students do not have knowledge regarding the test to determine seroconversion for HBV, despite the educational programs and specific material published for the dental community $(12,16)$. Biological risk is a concern for oral health professionals, as they run a 3-to-6-fold greater risk of infection than the general population (16).

Care taken with burs decreased over the 10-year interval. Burs come into contact with saliva and occasionally blood. They therefore must be sterilized. The sterilization process is one of the most efficient infection control methods and its use must be recommended in dental routine $(1,16)$.

The lack of knowledge regarding autoclave use is possibly related to the delegation of the sterilization 
practice to Sterilization Centers at universities. However, this fact is worrisome, as future dentists will be responsible for this procedure later on.

Fourth year dental students treated an average of 2 patients in a period of $4 \mathrm{~h}$. This number does not make it difficult to adopt the correct infection control procedures and can therefore not be the explanation for why many of them are transgressing standardized precaution rules.

Dental schools should focus on strategies to ensure suitable attitudes and behavior concerning infection control procedures. Dental schools could offer opportunities for students to analyze their own experiences in the dental clinic from the perspective of infection control. The approach proposed by Machado-Carvalhais et al. (18) can be adopted, as it offers the advantage of sensitizing students to their attitudes in order to change their behavior and consequently improve their quality of life.

In conclusion, the attitudes and behavior of dental students regarding infection control over the 10 -year evaluation period were worrisome. There was no evolution for most variables, such as the use of IPE, disinfection of the dental chair and vaccination against hepatitis B. In addition, the students' performance worsened over the 10-year period with regard to some procedures, such as the sterilization of burs and the use of protective eyewear.

\section{RESUMO}

Este estudo comparou as atitudes e comportamento de estudantes de odontologia do quarto ano em relação às medidas de controle de infecção em 1995 e 2005 . Questionários foram aplicados a 592 estudantes em cinco diferentes faculdades de odontologia em $1995(n=350)$ e $2005(n=242)$. Testes de qui-quadrado e testes exatos de Fisher foram utilizados. O nível de significância estatística utilizado foi $\mathrm{p}<0,05$. As taxas de respostas foram iguais a $90,3 \%$ em 1995 e $81,0 \%$ em 2005 . Não houve melhora no uso de luvas $(\mathrm{p}=0,316)$, máscaras $(\mathrm{p}=0,572)$ ou gorros $(\mathrm{p}=0,862)$ entre 1995 e 2005 . Houve uma diminuição na frequência do uso de óculos de proteção em 2005 ( $<<0,001)$. Nenhum estudante utilizou o equipamento de proteção individual corretamente. Houve uma diminuição no relato de esterilização de brocas em 2005 comparado com $1995(\mathrm{p}<0,001)$. Nenhum estudante foi capaz de descrever o uso correto da autoclave. Desinfecção e uso de barreira na cadeira odontológica foi corretamente realizado por uma minoria de estudantes em $1995(2,8 \%)$ e $2005(6,1 \%)$ $(p=0,069)$. A maioria dos estudantes descartava corretamente os instrumentais pérfuro-cortantes em ambos os anos $(\mathrm{p}=0,749)$. As atitudes e comportamentos desses estudantes de odontologia em relação ao controle de infecção são preocupantes. Não houve melhora, e para alguns parâmetros, houve uma piora na realização desses procedimentos no período avaliado.

\section{REFERENCES}

1. Kohn WG, Collins AS, Cleveland JL, Harte JA, Eklund KJ, Malvitz DM, et al.. Guidelines for infection control in dental healthcare settings-2003. MMWR 2003;52:1-61.

2. Hazelkorn HM. Do Dentists have sufficient information about their patients to control infection? J Dent Educ 1990;54:149-152.

3. Duffy RE, Cleveland JL, Hutin YJ, Cardo D. Evaluating infection control practices among dentists in Vâlcea, Romania, in 1998. Infect Control Hosp Epidemiol 2004;25:570-575.

4. Elkarim IA, Abdulla ZA, Yahia NA, Al Qudah A, Ibrahim YE. Basic infection control procedures in dental practice in KhartoumSudan. Int Dent J 2004;54:413-417.

5. Di Giuseppe D, Marinelli P, Angelillo IF. A survey of knowledge, attitudes, and behavior of Italian dentists toward immunization. Vaccine 2007;25:1669-1675.

6. Mehtar S, Shisana O, Mosala T, Dunbar R. Infection control practices in public dental care services: findings from one South African Province. J Hosp Infect 2007;66:65-70.

7. Myers R, Larson E, Cheng B, Schwartz A, Da Silva K, Kunzel C. Hand hygiene among general practice dentists: a survey of knowledge, attitudes and practices. J Am Dent Assoc 2008;139:948-957.

8. Utomi IL. Attitudes of Nigerian dentists towards hepatitis B vaccination and use of barrier techniques. West Afr J Med 2005;24:223-226.

9. Freire DN, Pordeus IA, Paixão HH. Observing the behavior of senior dental students in relation to infection control practices. J Dent Educ 2000;64:352-356.

10. Galli MG, Tesauro M, Bianchi A, Consonni M. Evaluation of Milan University Dental Students' knowledge of health and hygiene risks related to clinical work. Minerva Stomatol 2006;55:391-400.

11. Qudeimat MA, Farrah RY, Owais AI. Infection control knowledge and practices among dentists and dental nurses at a Jordanian University Teaching Center. Am J Infect Control 2006;34:218-222

12. Souza RA, Namen FM, Galan J, Vieira C, Sedano HO. Infection control procedures among senior dental students in Rio de Janeiro State, Brazil. J Public Health Dent 2006;66:282-284.

13. Machado-Carvalhais HP, Martins TCPM, Ramos-Jorge ML, Magela-Machado D, Paiva SM, Pordeus IA. Management of occupational bloodborne exposure in a dental teaching environment. J Dent Educ 2007;71:1348-1355.

14. Sofola OO, Folayan MO, Denloye OO, Okeigbemen SA. Occupational exposure to bloodborne pathogens and management of exposure incidents in Nigerian Dental Schools. J Dent Educ 2007;71:832-837.

15. Acosta-Gío AE, Borges-Yañes AS, Flores M, Herrera A, Jerónimo J, Martínez M, et al.. Infection control attitudes and perceptions among dental students in Latin American: implications for dental education. Int Dent J 2008;58:187-193.

16. Brasil. Ministério da Saúde. Controle de infecção e a prática odontológica em tempo de AIDS: manual de condutas. Brasília: Ministério da Saúde, 2000. Available from http://www.aids.gov.br/ final/biblioteca/manual_odonto.pdf (Latest access June 25, 2009)

17. Sampson E, Dhuru VB. Infection control in North American Dental Schools. J Dent Educ 1989;53:532-537.

18. Machado-Carvalhais H, Ramos-Jorge ML, Auad SM, Martins LH, Paiva SM, Pordeus IA. Occupational exposure to potentially infectious biological material in a dental teaching environment. J Dent Educ 2008;72:1201-1208. 